\title{
THE EFFECTIVENESS OF THE 5E's MODEL WITH ANALOGY IN PROMOTING STUDENTS' DEEP UNDERSTANDING AND ATTITUDES TO LEARN SCIENCE IN BIOLOGY LEARNING
}

\author{
Purnomo ${ }^{1)}$ \\ Tjandrakirana ${ }^{2)}$ \\ Ibrahim $^{3)}$ \\ ${ }^{1)}$ Postgraduate student of Science Education Program, Universitas Negeri Surabaya \\ 2) Professor at Biology Department, Mathematics and Natural Sciences Faculty, Universitas Negeri Surabaya \\ ${ }^{3)}$ Professor at Biology Department, Mathematics and Natural Sciences Faculty, Universitas Negeri Surabaya \\ e-mail: mas.arisrudi@gmail.com
}

\begin{abstract}
In evaluating the effectiveness of the 5Es model with analogy to providing access of deep understanding and attitudes to learn science, a case study research was brought involving 27 undergraduates who took The Human Anatomy and Physiology course. The data gathered were then analyzed using qualitative descriptive technique. The results informed that most students were successful to have deep understanding towards abstract concepts showing by grade of at least $C$ or acceptable level and good attitudes to learn science within which all students possessed the same perception corresponding to interest and enjoyment regardless any different level of achievement. Overall, it could be concluded that the 5Es model with analogy was quietly effective to make deep understanding and attitudes to learn science appear in students' learning.
\end{abstract}

Keywords: student deep understanding, student attitudes, the 5Es model, and analogy

\begin{abstract}
Abstrak: Dalam mengevaluasi keefektifan model 5Es dengan analogi terhadap pemahaman mendalam dan sikap belajar sains, sebuah studi kasus dilakukan dengan melibatkan 27 mahasiswa yang memprogram Mata Kuliah Anatomi dan Fisiologi Manusia. Data yang diperoleh kemudian dianalisis dengan metode deskriptif kualitatif. Hasil penelitian tersebut menginformasikan bahwa umumnya siswa berhasil untuk memahami konsep yang abstrak secara mendalam yang ditunjukkan dengan nilai minimal C dan memiliki sikap belajar sains yang baik terkait dengan kesenangan dan minat belajar tanpa menghiraukan pencapaian hasil belajar mereka. Oleh karena itu, dapat simpulkan bahwa model pengajaran $5 E$ dan analogi terbukti efektif untuk memunculkan pemahaman konsep secara mendalam dan sikap belajar sains.
\end{abstract}

Keywords: pemahaman konsep secara mendalam, sikap belajar sains, model $5 E$ dan analogi.

\section{Introduction}

As part of natural sciences focusing on all about life, Biology usually contains many concepts which sometimes are abstract and complex, particularly if it deals with what happens in cells that involves biochemical reactions. Unfortunately, all of the concepts are taught using traditional teaching approach (Chinwe \& Chinyere, 2010) and this causes two prominent problems. First, traditional teaching produces negative impact on students' deep understanding. Urey and Chalik (2008) contended that the central focus of such a teaching style is memorization, and therefore it leads to make the concepts much more abstract and difficult. In line with this, Atweh (2000) asserted that capability of just memorizing the concepts affect students to only have fragmented pieces information rather than integrated knowledge. Hence, students cannot build their understanding comprehensively, but profoundly lack the notion towards concepts. Secondly, students' attitudes of learning science can also significantly decrease. It is related to how the traditional teaching just gives few opportunities to them interacting towards one another and experiencing concept exploration (Trumper, 2006). Hence, there is no doubt that due to those weaknesses, only 35 to $45 \%$ of undergraduates who enroll in The Anatomy and Human Physiology course as a compulsory subject at Biology Department of The State University of Surabaya get qualified scores to pass the subject matter (Biology Department, 2012).

To solve the problem above, many teaching instructions are available in books to choose for lectures. However, since the eagerness to take science back into its nature has prominently appeared to be implemented in today's Biology curriculum (National Research Council as cited in Bass, Contant, \& Carin, 2009, p. 87), the most recent science teaching instruction that brings lots of supports to it is inquiry. Inquiry is considered as a way to assist students in experiencing science and making sense of how science is born by stimulating their higher curiosity and enhancing their constructing understanding as constructivists have suggested (Bybee, 2006, p. 2). Bybee et al. (2006) in particular have successfully formulated the 5Es model comprised of Engagement, Exploration, Explanation, Elaboration, and Evaluation with essence of inquiry. These five phases include features that are able to promote students to actively learn what students need to understand, and this is what they called teaching for understanding.

Some research was done to empirically support the 5Es model as a successful teaching instruction in terms of 
what already discussed. Patro (2008), first of all, proved that the 5Es model can help students generate their understanding towards the aerobic cell respiration topic that can be looked at students' ability of using their own words to explain the concepts. Related to attitudes issues, secondly, Lavoie (1999) found that during exploration and elaboration phases, students tend to challenge themselves with their work and argumentative reasoning through student-student discussion. As an inevitable result, they will be more motivated to enjoy and be interested to learn biology while developing the meaning of the concepts.

To ensure that the 5Es model employed is effective, it needs to be applied on topic which consists of mainly abstract concepts. As part of biological topic, the human nervous system is considered to have such as how the human nervous system works and how ions move during impulse transmission. Related to these, the 5Es model apparently can help to solve the problems because through exploration processes students will be engaged to more sophisticatedly science thinking, but the other shortcoming may appear due to incapability of visualizing the unobservable phenomena and some students may not be able to see how the concepts of nervous system works without any help of images in their mind (Bean et al, 1996).

In dealing with such issues, Orgill and Thomas (2007) suggested the use of analogy as a complement aspect while implementing the 5Es model, assuming that the analogical images can generate two advantages to students. Firstly, they will bring lots of attraction and access to make the concepts mentally visualized in students' mind. Vasniadou and Brewer as cited in Bean et al. (1990) theorized that the formation of understanding concepts within science area needs more complex mental process of thinking and the analogy can help solve this issue. Secondly, the familiar language within range of analogy helps students get ease to study biological concepts. Orgill and Thomas (2007) argued the language of analogy takes the students' mind closer to the language concepts which usually consist of sophisticated terminologies.

By considering those arguments and the research results, this research will try to employ the combination of both the 5Es model and analogy to help students learn the human nervous system topic more easily. To make it obvious, it is also developed the teaching and learning packages in order to support the purpose of this research. However, the development of those is not the focus of this research, since the effectiveness of using both the 5Es and analogy is still the central problem. It is hoped then that the 5Es model with analogy can be effective for providing deep understanding of concepts to the students and moving their attitudes to learn biology into positive state.

\section{Methods}

A. Research Subjects
The subjects of this research were selected using nonprobability sampling (Cohen \& Morrison, 2008, p. 258). It involved 27 undergraduates majoring Biology Education from international Biology class who took The Human Anatomy and Physiology course in odd semester. They varied in socio-economic backgrounds, genders, and ages around 19 up to 21 years old.

\section{B. Research Design}

This research carried out case study as a design with only one unit of analysis which was then divided into two subunits of analysis (Yin, 2003, p. 20). The first subunit was student deep understanding, whereas the second subunit was student attitudes (enjoyment and interest).

\section{Research Procedures}

This research employed three different steps of technical procedures, namely, preparation, validation, and implementation. Each of which will be explained below.

Preparation. Preparation step was conducted to prepare teaching and learning package alongside with research instruments for data collection.

Validation. Validation took place to ensure whether the teaching and learning package as well as the instruments were matched with the research objectives, the level of students' cognitive level, and were well structured. In doing so, the experts involved. They The evaluated the instruments and the learning package in terms of complexity of contents, language being used, and hierarchical aspects of those. To make it better, students' ideas were also used to crosscheck the result of validation when it came to use in field. In results, all of the teaching package and research instruments were considered as good and excellent to be used in this research.

Implementation. The implementation of this research involved both teaching and data record. Those two activities happened simultaneously at which they were hard to separate in order to make boundaries.

It took two meetings for implementing the phases of $5 \mathrm{Es}$ model with analogy. In the first meeting, the students were offered with two phases, engagement and exploration. Since they had already possessed the worksheet, they could do the assigned tasks on it. During activities, research diary was used to observe any events which contributed to and resulted from the success of how the phases were conducted. Besides research diary, rubric of performance in doing the lab work and students' affective abilities sheet were also utilized for evaluating learning activities while the students were collaboratively working in the exploration phase.

In the second meeting, three other phases, explanation, elaboration, and evaluation were employed. The students built up explanation and did oral presentation for communicating their findings to others. What students achieved in these activities were then assessed using rubric. In the elaboration phase, the students were asked about new problem at which they had to 
implement what they had learned to other situation. The record of data was done using research diary. The last session provided evaluation phase for confirmation purposes whether all the students had understood about the learning materials. At time, observation using research diary was employed. Though the meetings had already finished, the collection of data was not done at all. Interview and students' paper-pencil test were done a week after. These functioned not to disrupt the learning processes. D. Technique of Data Collection

There were three different ways to collect the data. The first was observation included the use of research diary and some other observation sheets including lesson plan completion and student affective abilities. Secondly, paperpencil and performance test were also used to obtain the data for gaining information about student comprehension of concepts. In this, rubrics were utilized. The last way was interview functioning to deepen information gathering from students' mind in order to synchronize with all aspects being measured and observed.

\section{E. Technique of Data Analysis}

The data were analyzed using qualitative descriptive technique. The quantitative and qualitative data were synchronized to get understanding of a phenomenon.

Before reached to the synchronized data, there

were several ways of analyzing the data this research used. First was clustering, referring to grouping the data that looked quietly similar into particular categories based on the research questions. Second, after being grouped the data were then reduced into a focused one, meaning a huge amount of data was narrowed down in order to get specified information. The last step was combining both quantitative and qualitative data to make supports towards one another. The facts captured by observation and interview were strengthened with evidence from numerical data.

\section{RESULTS AND DISCUSSION}

Judging the effectiveness of the 5Es model with analogy includes how this method can deepen students' understanding of concepts and promote good attitudes while learning science, especially for enjoyment and interest. Through this part each of which will be elucidated further.

\section{A. Promoting Student Deep Understanding}

In exploring how the 5Es model with analogy can promote student deep understanding towards biology concepts, it needs to involve two major components of data including the results from paper-pencil test and oral presentation.

\section{Student Paper-Pencil Test}

Paper-pencil test is conducted to evaluate students' mastery of concepts. According to its results, most students have scores above $\mathrm{C}$ that related to the university's scoring rule (Unesa standard score) is minimal requirement to get pass through the subject matter, but only a few of them gained below, that is, four students who are accredited to have score D or $15 \%$ from the total sample as seen in the diagram below.

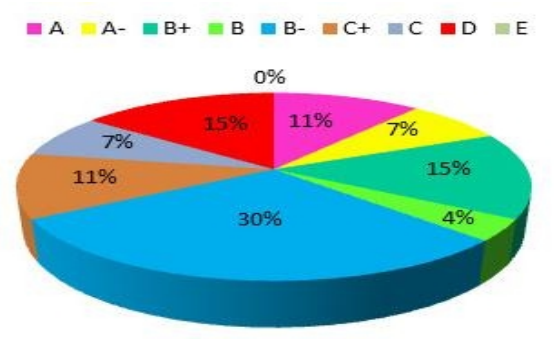

Figure 3.1. Achieved alphabetical scores on students' mastery of concepts

By knowing the fact above, the inquiry within the 5Es model has been believed to have strengths for support to knowledge pursuing students. It gives advantages wherein students will have more profitable challenges to conquer in their learning and make them well understand the concepts they learn. In light of research, conducted through meta-analysis, Furtak, Seidel, Iverson, and Briggs (2012) revealed that the inquiry provides cognitive dimension to students which means in the process of inquiry students try to look for evidence. Thus, it advances students with performance to acquire knowledge from several dimensions, not just straightforward process by which the teachers transfer the information to their students.

Besides the strengths of the 5Es model itself, the analogy embedded in the third phase of it also obviously raises students' success as well, in terms of grasping knowledge. Most of students are successful to answer the question that asks them about impulse propagation along a single neuron or between two different neurons. Regarding to this, Gentner and Holyoak (1997) contended that the analogy can somehow help build explanation through aligning the familiar one with the abstraction wants to be elucidated. In doing so, however, they added that it must be carefully designed by choosing appropriate analog to be employed to target. In addition, Holyoak and Thagard (1989) echoed by mapping the selected components of analog and target, the analogy can have its positive impact to learning. In line with those experts, this research simply uses the way a series of dominos falls down as the analog for impulse propagation, known as target, at which this analogy has potential to explain abstract concepts.

\section{Student Oral Presentation}

Besides looking at the results of paper-pencil test, students also take a part in oral presentation. The results inform that nearly all groups have been successful to communicate their understanding towards concepts.

Table 3.1 Results of student oral presentation

\begin{tabular}{|c|c|c|c|c}
\hline \multirow{2}{*}{$\begin{array}{c}\text { Student } \\
\text { group }\end{array}$} & $\begin{array}{c}\text { Introducing } \\
\text { topic }\end{array}$ & $\begin{array}{c}\text { Developing } \\
\text { understandin } \\
\text { g of concepts }\end{array}$ & $\begin{array}{c}\text { Answering } \\
\text { questions }\end{array}$ & $\begin{array}{c}\text { Making } \\
\text { conclusion }\end{array}$ \\
\cline { 2 - 5 } & Level & Level & Level & Level \\
\hline Group 1 & Excellent & Good & Good & Good \\
\hline Group 2 & Good & Good & Acceptable & Good \\
\hline Group 3 & Excellent & Good & Good & Good \\
\hline Group 4 & Good & Excellent & Acceptable & Good \\
\hline Group 5 & Acceptable & Good & Acceptable & Good \\
\hline
\end{tabular}


As seen in the table 4.2, four major aspects of assessment have been successfully done by students. Their capability in doing so varies from acceptable to excellent. Among the aspects, only two which are vital, namely, developing understanding of concepts and making conclusion. In these areas, students show mostly good point and only one group outperforms the others with excellent point. This success, according to Wentzel as cited in McInerney and McInerney (2010, p. 247), appears due to the availability of collaborative working while learning the topic. Three different ways causing this success have been argued by him. Firstly, giving in mind those students who are socially responsible will greatly pay attention to the task completion and the quality of work at the same time. Thus, it provides benefits to group in preparing and doing oral presentation. Secondly, the social interaction within groups can promote good behavior among teammates. At times, good behavior showed by less capable students will strengthen the relationship between them and more capable students into positive state. As an inevitable result, the more capable students will share their understanding of concepts towards less capable students and therefore the academic increase seems to happen. Thirdly, collaborative working makes students to be more responsible to engage in academic work. It is because they feel that pursuing success in that task will give advantages to group where they are involved in.

\section{B. Promoting Student Attitudes to Learn Science}

As discussed earlier, student attitudes to respond are enjoyment and interest. These two things will not be separated in discussion; rather they are collaborated to strengthen towards one another.

In earlier, students perceive that the learning cycle of the 5Es model with analogy is confusing for its own shake. It can be traced from the interview results by which students comment as follow:

"Although I felt a bit confused at first, I still felt curious when following further step of the 5Es model". (1)

Based on that quote, O'Brien as cited in Woolfolk, Hughes, and Walkup (2008, p. 345) stated that students mind learning does not merely encompass balanced, synchronized, and rhythmical processes. It also involves a huge amount of chaos and conflict that can make them feel stressful and confused. Hence, students need to adapt to rebalance their mind (McInerney \&McInerney, 2010, p. 37 ) towards the new learning situation brought by the 5Es model of instruction.

When it comes to further step, mostly students start to enjoy the learning process due the availability of active working, such as having hands-on activities and making analogy for explaining the phenomenon of how the nervous system works. Low, middle, and high

achieving students perceive the same thing, but they are different in what they are enjoying as seen in the quotes below:

"I found myself interested in just doing the lab work. I never dissected the frog to find nerve and muscle". (Low achieving students) (2)
"I enjoyed the activities when I saw how the instruments work with the frog's nerve and muscle, it amused me". (Middle achieving students) (3)

"I think I really enjoyed the lab work because I could combine my thinking and my lab work skills although I had difficulties in doing so for some time”. (High achieving students) (4)

The quotes state that students' attitudes are in positive states. Hofstein and Naaman as cited in Areepattamannil (2012) argued that it is because students enjoy and be interested in integrating their cognitive abilities with senses and motions, and therefore these may sustain students' motivation to learn. In addition to this, the research diary notices that besides enjoying the learning activities, students also successfully bring the essence of the 5Es model.

"Students knew the reasons that stood behind the steps of procedures to do the lab work" (5)

Since the 5Es model is incorporated with analogy, especially for the third phase of the 5Es, most students claimed confidently that they are able to explain the concepts of the nervous system when someday they are asked. For this, analogy has portion to help them doing so.

"The strength was that the 5Es model submerged the analogy as I perceived it to be useful for helping me learn. If you ask me to explain the concepts again, I can do it". (6)

Regarding the students' attitudes that are focused on students' enjoyment and interest, the other observation tries to point out the occurrences that may imply to mirror those attitudes. Through observation, students' affective abilities are then recorded using rubrics. Such affective abilities are the seriousness and the collaborative working while doing the lab work.

According to the results of affective observation in the table 4.3, students show good results at which they accommodate the willingness to do the lab work within which their scores vary from 3.0 to 4.0 or good to excellent. Due to this reality it is known that the 5Es model with analogy can be promoting students' enjoyment and interest while learning the nervous system topic.

Table 3.2 Scores of students' affective abilities

\begin{tabular}{|c|l|c}
\hline $\begin{array}{c}\text { Student } \\
\text { group }\end{array}$ & \multicolumn{1}{|c|}{ Component of evaluation } & $\begin{array}{c}\text { Average } \\
\text { Scores }\end{array}$ \\
\hline \multirow{2}{*}{ Group 1 } & Collaborative working & 3.5 \\
\cline { 2 - 3 } & Seriousness of doing the lab work & 4.0 \\
\hline \multirow{2}{*}{ Group 2 } & Collaborative working & 3.5 \\
\cline { 2 - 3 } & Seriousness of doing the lab work & 3.5 \\
\hline \multirow{2}{*}{ Group 3 } & Collaborative working & 4.0 \\
\cline { 2 - 3 } & Seriousness of doing the lab work & 4.0 \\
\hline \multirow{2}{*}{ Group 4 } & Collaborative working & 3.0 \\
\cline { 2 - 3 } & Seriousness of doing the lab work & 3.5 \\
\hline \multirow{2}{*}{ Group 5 } & Collaborative working & 3.5 \\
\cline { 2 - 3 } & Seriousness of doing the lab work & 3.0 \\
\hline
\end{tabular}

Since the observation reveals those facts, it is confidently said that students have good attitudes to learn the topic, in this case the nervous system, through lab work activities. 
For this, Rheinberg (1996) has proposed the term to meaningfully understand this thing, interest- guided activities, as introduced by Schiefele, Haußer, and Schneider in 1979, meaning that the activities are intended to have more incentives to students while they are doing those. The incentives might be relevant to students' pursuit of knowledge are enjoyment and interest.

\section{Relation between student deep understanding and attitudes}

Since the research results point out that the 5Es model is quite successful to make students possess deep understanding of concepts and good attitudes to learn science, it may be helpful to figure out whether there may be some relation between those two things.

In this research, the relation between deep understanding and attitudes to learn science may blur because all kinds of students (low, middle, high achieving students) seem to perceive the same thing.

\section{Suggestion}

Although the results have successfully pointed out that the 5Es model with analogy is effective to promote students' deep understanding and attitudes to learn science, two suggestions should be taken into account for further refinement as follows.

1. Since all students perceive the 5Es model with analogy is enjoying and interesting, it is important to investigate in a deeper way about what students want to achieve, and therefore the steps of the 5Es model can be modified further.

2. Although this research points out that there is no clear connection between attitudes and students' deep understanding of concepts, there will be another way to determine the straight line of the connection, such as taking assessment side by side with what students do and achieve before, during, and after the learning process. Also, student-teacher discussion can strengthen the result of it.

\section{REFERENCES}

Areepattamannil, S. 2012. Effects of Inquiry-Based Instruction

on Science Achievement and Interest in Science: Evidence from Qatar. The Journal of Educational Research. 105:2, 134 Doi: 10.1080/00220671.2010.533717

Atweh, B. 2002. The Social Turn in Understanding Learning and its Implication for Facilitating Learning. Queensland: Queensland University of Technology.

Furtak, Seidel, Iverson, \& Briggs. 2012. Experimental and Quasi-Experimental Studies of Inquiry-Based Science Teaching: A Meta-Analysis. Review of Educational Research. Vol:82, No:3 p.300 -329

Gentner, D. \& Holyoak, K. J. 1997. Reasoning and Learning by

Analogy (Introduction). American Psychologist. Volume
52, No. 1, pp. 32-34

Holyoak, K. J. \& Thagard, P. 1989. Analogical Mapping by Constraint Satisfaction. Cognitive Science. Volume 13, pp. 295-355.

Lavoie, D. R. 1999. Effect of Emphasizing HypotheticoPredictive Reasoning within the Science Learning Cycle on High School Student's Process Skill and Conceptual Understanding in Biology. Journal of Research in Science Teaching. Vol. 36, No. 10, p. 1127-1147

McInerney, D. M. \& McInerney, V. 2010. Educational Psychology: Constructing Learning. $5^{\text {th }}$ Edition. New South Wales: Pearson.

Orgill, M. K. \& Thomas, M. 2007. Analogies and the 5E Model. Science Teacher, 74, 40-45.

Patro, E. T. 2008. Teaching Aerobic Cell Respiration Using the 5Es. The American Biology Teacher. Vol. 70 , No. 2

Rheinberg, F. 1996. Motivation and Learning Activities. How Learning Could Proceed. Psychologisches instituteder universitat Heidelberg. p. 47-51.

Trumper, R. 2006. Factors Affecting Junior High School Students' Interest in Biology. Science Education International. Vol. 17, No. 1, p. 31-48.

Urey, M. \& Calik, M. 2008. Combining Different Conceptual Change Methods within 5E Model: A Sample Teaching Design of Cell Concept and Its Organelles. Asia Pacific.

Forum on Science Learning and Teaching. Vol. 9, No.2. Woofolk, A., Hughes, M., \& Walkup, V. 2008. Psychology in 